\title{
ASSESSMENT OF HEAVY METALS CONTENT IN SOME MEDICINAL PLANTS AND SPICES COMMONLY USED IN ROMANIA
}

\author{
ELISABETA MARINESCU ${ }^{1}$, ALINA MIHAELA ELISEI ${ }^{1}$, ANA CLARA APROTOSOAIE $^{2 *}$, \\ OANA CIOANCA ${ }^{2}$, ADRIANA TRIFAN ${ }^{2}$, ANCA MIRON $^{2}$, SILVIA ROBU ${ }^{1}$, CAMELIA IFRIM $^{4}$, \\ MONICA HĂNCIANU ${ }^{2}$
}

\author{
1 "Dunărea de Jos" University, Faculty of Medicine and Pharmacy, 35 Al. I. Cuza Street, Galați, Romania \\ 2 "Grigore T. Popa" University of Medicine and Pharmacy, Faculty of Farmacy, 16 Universității Street, Iaşi, Romania \\ 3 “Anastasie Fătu” Botanical Garden, 7-9 Dumbrava Roșie Street, Iași, Romania
}

*corresponding author: ana.aprotosoaie@umfiasi.ro

Manuscript received: June 2020

\begin{abstract}
The present study was designed to investigate the level of six heavy metals (arsenic, cadmium, cooper, iron, mercury and lead) in both wild-growing and packaged samples from twelve commonly used medicinal plants and spices in Romania. The concentrations of all heavy metals, except mercury and lead, were within permissible limits in the analysed plant samples. The wild-growing sample of Tilia cordata and some packaged samples of Origanum vulgare and Thymus vulgare contained higher levels of mercury than $0.1 \mathrm{mg} / \mathrm{kg}$. The concentrations of lead exceeded the limit recommended by the EU $(0.3 \mathrm{mg} / \mathrm{kg})$ for some samples of Achillea millefolium, Matricaria chamomilla, Mentha piperita, Ocimum basilicum, Origanum majorana and Tilia cordata. The findings of the study highlight the need for constant monitoring of heavy metals residues in order to ensure the quality and safety of herbal products.
\end{abstract}

\section{Rezumat}

Subiectul studiului prezent 1-a constituit evaluarea nivelelor a 6 metale grele (arsenic, cadmiu, cupru, fier, mercur și plumb) în probe colectate din flora spontană şi probe ambalate sub formă de ceaiuri medicinale aparţinând la 12 specii de plante medicinale şi condimente frecvent utilizate în România. Concentrațiile tuturor metalelor grele au fost mai mici față de limitele permise, cu excepția valorilor obținute pentru mercur şi plumb. Proba colectată din flora spontană pentru Tilia cordata şi unele probe ambalate de Origanum vulgare şi Thymus vulgare conţin nivele de mercur mai mari de $0,1 \mathrm{mg} / \mathrm{kg}$. Conținutul în plumb a depăşit limita recomandată de UE $(0,3 \mathrm{mg} / \mathrm{kg})$ în cazul unor probe de Achillea millefolium, Matricaria chamomilla, Mentha piperita, Ocimum basilicum, Origanum majorana şi Tilia cordata. Rezultatele studiului evidențiază nevoia unei monitorizări constante a prezenței şi nivelului metalelor grele în vederea asigurării calității şi siguranței la administrare a produselor din plante medicinale.

Keywords: heavy metals, medicinal plants, spices, contamination

\section{Introduction}

Medicinal plants and plant-derived products play a significant role in the strategies for the assessment of global health and their use is rapidly rising. WHO reported that about $80 \%$ of the population in developing countries relies on traditional herbal medicine for their primary healthcare [29]. These findings impose major concerns on the quality and safety of herbal products in order to provide appropriate and effective therapy [12, 15, 16]. Among the main safety risks related to herbal medicines is contamination with heavy metals. The medicinal plants may be contaminated with toxic heavy metals during cultivation, harvesting or processing stages [25]. Also, the environmental pollution that includes industrial waste, traffic emissions and some agricultural activities can affect significantly the heavy metals content in medicinal plants. The uptake and accumulation of heavy metals in vegetal tissues can directly affect plant growth and can clinically pose major threat for the human health. Excessive levels of these elements can cause central nervous system toxicity (mercury, lead, arsenic), produce kidney and liver damage (mercury, lead, cadmium, cooper), or respiratory dysfunction (cadmium), and have adverse effects on skin, bones and teeth (nickel, cadmium, cooper, chromium) $[2,11]$. Also, large amounts of iron might cause abdominal and skin injuries [2]. Thus, the assessment of metal contamination in herbal raw materials is an important step in the control of plants' quality. Nevertheless, there is limited data in terms of heavy metals contamination of medicinal and culinary plants used in Romanian traditional medicine or diet. Taking all this into account, the present study was designed to investigate the level of six heavy metals (arsenic-As, cadmium-Cd, cooper-Cu, iron-Fe, mercury- 
FARMACIA, 2020, Vol. 68, 6

$\mathrm{Hg}$ and lead- $\mathrm{Pb}$ ) in some commonly used medicinal plants and spices in Romania.

\section{Materials and Methods}

\section{Plant material}

A total of forty-two samples belonging to six medicinal plants and six spices commonly used in Romania were analysed. For each medicinal plant species, four samples were analysed as follows: a sample collected from spontaneous flora of Galaţi County, Romania, and three samples provided by different indigenous producers as herbal teas (packaged samples). In the case of spices, for each plant species, three samples were analysed, namely: a sample collected from spontaneous flora of Galați County, Romania, and two samples purchased from local suppliers. Table I shows the herb samples investigated in this study and some characteristics of the plant species [26].

Table I

Samples and some characteristics of selected medicinal plants and spices

\begin{tabular}{|c|c|c|c|c|c|}
\hline \multirow[t]{2}{*}{ Plant species } & \multicolumn{2}{|c|}{ Samples } & \multirow{2}{*}{$\begin{array}{c}\text { Common } \\
\text { name }\end{array}$} & \multirow{2}{*}{$\begin{array}{l}\text { Part } \\
\text { used }\end{array}$} & \multirow{2}{*}{$\begin{array}{c}\text { Main beneficial } \\
\text { effects }\end{array}$} \\
\hline & indigenous producers & spontaneous flora & & & \\
\hline \multicolumn{6}{|l|}{\begin{tabular}{|l} 
Medicinal plants \\
\end{tabular}} \\
\hline Achillea millefolium $\mathrm{L}$. & AM1, AM2, AM3 & AM4 & yarrow & flowers & $\begin{array}{l}\text { - eupeptic } \\
\text { - cholagogue } \\
\text { - carminative } \\
\text { - anti-inflammatory } \\
\text { - spasmolytic }\end{array}$ \\
\hline Calendula officinalis L. & $\mathrm{CO} 1, \mathrm{CO} 2, \mathrm{CO} 3$ & $\mathrm{CO} 4$ & marigold & flowers & $\begin{array}{l}\text { - choleretic } \\
\text { - anti-inflammatory } \\
\text { - spasmolytic } \\
\text { - wound healing } \\
\text { - antimicrobial } \\
\end{array}$ \\
\hline Hypericum perforatum $\mathrm{L}$. & HP1, HP2, HP3 & HP4 & $\begin{array}{l}\text { St. John's } \\
\text { wort }\end{array}$ & $\begin{array}{l}\text { aerial } \\
\text { parts }\end{array}$ & $\begin{array}{l}\text { - choleretic } \\
\text { - anti-diarrheal } \\
\text { - antidepressive } \\
\text { - wound healing } \\
\text { - } \text { antimicrobial }\end{array}$ \\
\hline Matricaria chamomilla $\mathrm{L}$. & $\mathrm{MC} 1, \mathrm{MC} 2, \mathrm{MC} 3$ & MC4 & chamomile & flowers & $\begin{array}{l}\text { - spasmolytic } \\
\text { - carminative } \\
\text { - anti-inflammatory } \\
\text { - sedative } \\
\text { - antiulcer }\end{array}$ \\
\hline Ocimum basilicum $\mathrm{L}$. & OB1, OB2, OB3 & OB4 & basil & $\begin{array}{l}\text { aerial } \\
\text { parts }\end{array}$ & $\begin{array}{l}\text { - eupeptic } \\
\text { - spasmolytic } \\
\text { - carminative } \\
\text { - diuretic }\end{array}$ \\
\hline Tilia cordata Mill. & TC1, TC2, TC3 & TC4 & linden & flowers & $\begin{array}{l}\text { - expectorant } \\
\text { - spasmolytic } \\
\text { - sedative }\end{array}$ \\
\hline \multicolumn{6}{|l|}{ Spices } \\
\hline Anethum graveolens $\mathrm{L}$. & AG1, AG2 & AG3 & dill & leaves & $\begin{array}{l}\text { - carminative } \\
\text { - eupeptic } \\
\text { - diuretic }\end{array}$ \\
\hline Mentha piperita $\mathrm{L}$. & MP1, MP2 & MP3 & peppermint & leaves & $\begin{array}{l}\text { - choleretic } \\
\text { - cholagogue } \\
\text { - spasmolytic } \\
\text { - carminative } \\
\text { - anti-diarrheal } \\
\end{array}$ \\
\hline Origanum majorana L. & OM1, OM2 & OM3 & marjoram & $\begin{array}{l}\text { aerial } \\
\text { parts }\end{array}$ & $\begin{array}{l}\text { - eupeptic } \\
\text { - spasmolytic } \\
\text { - carminative } \\
\text { - sedative } \\
\text { - diuretic }\end{array}$ \\
\hline Origanum vulgare $\mathrm{L}$. & OV1, OV2 & OV3 & oregano & $\begin{array}{l}\text { aerial } \\
\text { parts }\end{array}$ & $\begin{array}{l}\text { - eupeptic } \\
\text { - spasmolytic } \\
\text { - carminative } \\
\text { - expectorant } \\
\text { - antimicrobial }\end{array}$ \\
\hline
\end{tabular}


FARMACIA, 2020, Vol. 68, 6

\begin{tabular}{|l|c|c|c|c|c|c|}
\hline \hline \multirow{2}{*}{ Plant species } & \multicolumn{2}{|c|}{ Samples } & $\begin{array}{c}\text { Common } \\
\text { name }\end{array}$ & $\begin{array}{c}\text { Part } \\
\text { used }\end{array}$ & $\begin{array}{c}\text { Main beneficial } \\
\text { effects }\end{array}$ \\
\cline { 2 - 5 } & indigenous producers & spontaneous flora & \multicolumn{2}{|l|}{} \\
\hline Spices & PC1, PC2 & PC3 & parsley & leaves & $\begin{array}{l}\text { - carminative } \\
\text { - diuretic } \\
\text { - antihypertensive } \\
\text { - haemostatic }\end{array}$ \\
\hline Thymus vulgaris L. & TV1, TV2 & TV3 & thyme & $\begin{array}{l}\text { aerial } \\
\text { parts }\end{array}$ & $\begin{array}{l}\text { - eupeptic } \\
\text { - spasmolytic } \\
\text { - carminative } \\
\text { - expectorant } \\
\text { - diuretic }\end{array}$ \\
\hline
\end{tabular}

Sample processing and heavy metals analysis The content of heavy metals in selected plants and spices was determined using atomic absorption spectrometry after wet digestion of the samples with $65 \% \mathrm{HNO}_{3}$ and $30 \% \mathrm{H}_{2} \mathrm{O}_{2}$ [30]. The analysis of $\mathrm{As}, \mathrm{Cd}$ and $\mathrm{Pb}$ was done using atomic absorption spectrometry with graphite furnace atomization (SpectrAA240Z spectrophotometer with GTA120 furnace, Varian, The Netherlands) [23, 25]. Flame atomic absorption spectrometry was performed for the analysis of $\mathrm{Fe}$ and $\mathrm{Cu}$ content (SpectrAA240FS spectrophotometer, Varian, The Netherlands) [23]. The Hg concentrations were determined by cold vapour atomic absorption spectrometry (SpectrAA240FS spectrophotometer, Varian, The Netherlands) [24]. High purity standards for heavy metals (Merck, Germany) were used as reference analytes and the calibration standards were prepared by appropriate dilution of their stock solutions. The concentrations of heavy metals were expressed as $\mathrm{mg} / \mathrm{kg}$.

Statistical analysis

Four determinations were performed for each sample and the mean and standard deviation were calculated.

\section{Results and Discussion}

The regulatory guidelines for heavy metals content in plants are presented in Table II. The results of the analysis of heavy metals in the selected medicinal plants and spices are summarized in Tables III and IV, respectively.

Arsenic (As). It is a highly toxic non-essential metalloid that significantly affects human health leading to gastrointestinal and hepatic disorders, hypotension, polyneuropathy, loss of sight and carcinogenic effects [19]. Plants are exposed to As mainly from anthropogenic activities such as mining and smelting, the use of Asbased pesticides in agriculture and of As-contaminated groundwater for irrigation purposes [7]. In our study, the level of As varied from less than 0.01 to 0.15 $\mathrm{mg} / \mathrm{kg}$ in medicinal plants samples (Table III) and from less than 0.01 to $0.78 \mathrm{mg} / \mathrm{kg}$ in spices, respectively (Table IV). Maximum concentrations of As were found in Tilia cordata and Petroselinum crispum packaged samples, respectively (TC3; PC1); in all samples of Hypericum perforatum, As was undetectable. In general, we noticed that the investigated plant samples contained extremely low concentrations of As. Only some samples of spices, mainly Petroselinum crispum (PC1, PC2), Thymus vulgare (TV2) and Origanum vulgare (OV2, OV3) showed higher values but all were below the acceptable limit (Table II and Table IV). The levels of As identified in this work are much lower than those noticed in other studies. Oprea et al. reported for samples of some medicinal plants from two areas belonging to the Baia Mare municipality, Maramureș County (Romania), concentrations of As ranging from 0.11 to $5.33 \mathrm{mg} / \mathrm{kg}$ [17]. These large amounts of As are primarily associated with specific metallurgical industry and soil pollution of Baia Mare [17], but contamination with As is important due to the fact that Romania is one of the countries having problems due to the natural arsenic groundwater [28].

Table II

Acceptable limits of the heavy metals in medicinal plants/culinary plants $(\mathrm{mg} / \mathrm{kg})$

\begin{tabular}{|l|c|c|c|c|}
\hline \multicolumn{1}{|c|}{ Limits } & Arsenic (As) & Cadmium $(\mathrm{Cd})$ & Mercury $(\mathrm{Hg})$ & Lead $(\mathrm{Pb})$ \\
\hline European Pharmacopoeia [6] & - & 1 & 0.1 & 5 \\
\hline FAO/WHO [30] & 1 & 0.3 & - & 10 \\
\hline EU [13] & - & 0.2 & - & 0.3 \\
\hline
\end{tabular}

Cadmium $(\mathrm{Cd})$ is a non-essential hazardous heavy metal that causes serious effects on the kidney, liver, vascular and immune system. Prolonged exposure to high-doses of Cd results in the Itai-Itai disease that is characterized by severe renal tubular dysfunction, ostomalacia and osteoporosis [20]. The combustion of fossil fuels, the use of phosphate fertilizers, non- ferrous smelters, mines and sewage sludge application are the major sources for the $\mathrm{Cd}$ contamination of plants [11]. This metal presents high rates of soil-toplant transfer such that it is a contaminant found in most human foodstuffs [20]. The levels of $\mathrm{Cd}$ were within allowable limits (Table II) in all samples of medicinal plants $(0.01-0.05 \mathrm{mg} / \mathrm{kg}$ ) (Table III) and 
FARMACIA, 2020, Vol. 68, 6

spices $(0.02-0.12 \mathrm{mg} / \mathrm{kg})$ (Table IV). The highest concentration of $\mathrm{Cd}$ was noticed for the sample of Anethum graveolens collected from spontaneous flora $(0.12 \mathrm{mg} / \mathrm{kg})(\mathrm{AG} 3)$. All samples of spices harvested from spontaneous flora have higher values of $\mathrm{Cd}$ levels compared to their packaged variants of different origin $(0.01-0.06 \mathrm{mg} / \mathrm{kg}$ vs. $0.05-0.12 \mathrm{mg} / \mathrm{kg})$ (Table IV). Cd was undetected in all samples of Hypericum perforatum, the sample of wild-growing Tilia cordata (TC4) (Table III) and some packaged samples of Origanum majorana (OM1) and Petroselinum crispum (PC1) (Table IV).

Table III

The content of heavy metals in selected medicinal plants

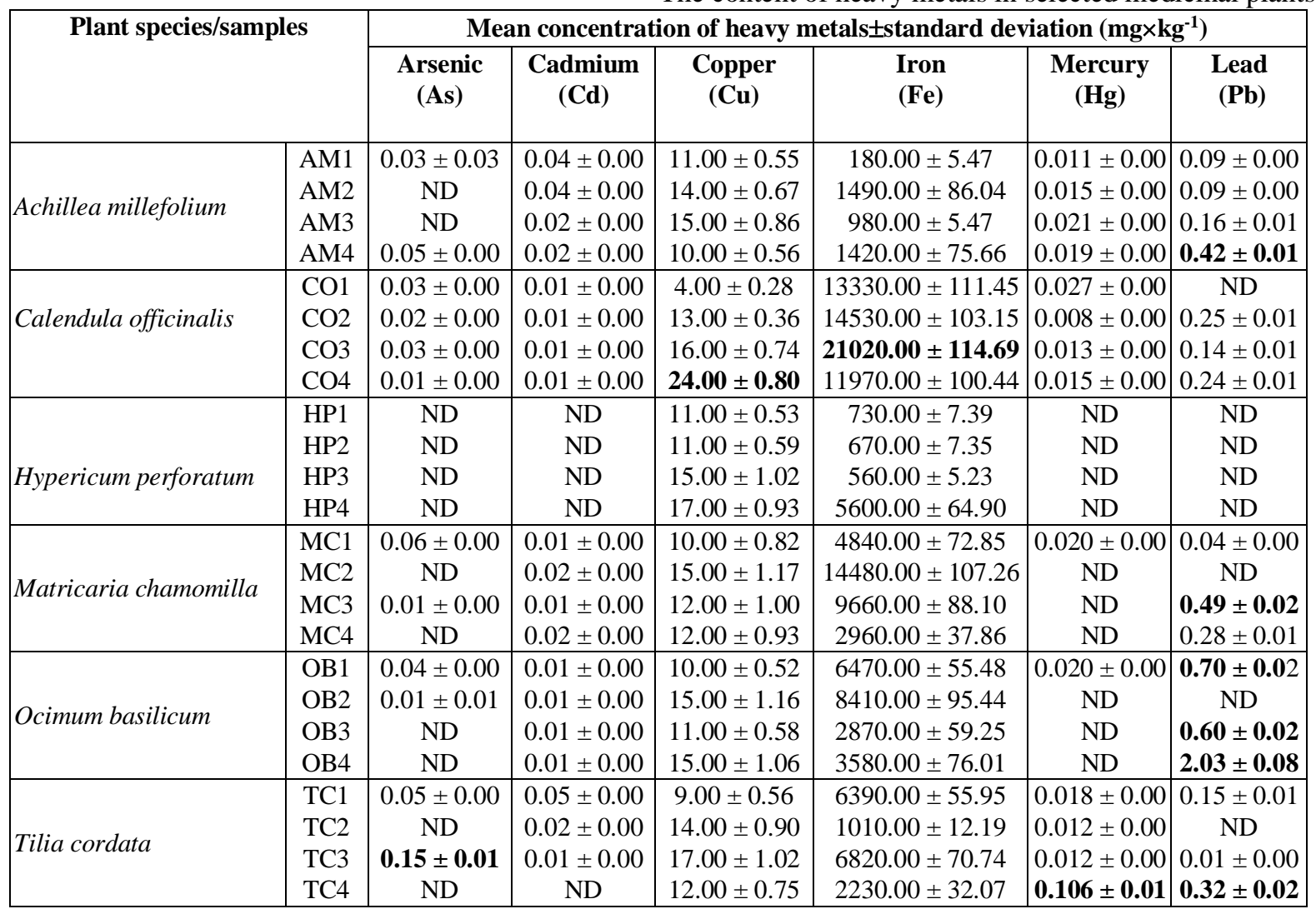

Table IV

The content of heavy metals in selected spices

\begin{tabular}{|c|c|c|c|c|c|c|c|}
\hline \multirow{2}{*}{\multicolumn{2}{|c|}{ Spices/Samples }} & \multirow{2}{*}{\multicolumn{6}{|c|}{ Mean concentration of heavy metals \pm standard deviation $(\mathrm{mg} / \mathrm{kg})$}} \\
\hline & & & & & & & \\
\hline Anethum graveolens & AG1 & \multirow{3}{*}{$\begin{array}{c}\begin{array}{c}\text { Arsenic } \\
\text { (As) }\end{array} \\
0.04 \pm 0.00 \\
\text { ND } \\
0.08 \pm 0.00\end{array}$} & \multirow{3}{*}{$\begin{array}{c}\begin{array}{c}\text { Cadmium } \\
(\mathrm{Cd})\end{array} \\
0.02 \pm 0.00 \\
0.04 \pm 0.00 \\
\mathbf{0 . 1 2} \pm \mathbf{0 . 0 1}\end{array}$} & \multirow{3}{*}{\begin{tabular}{|c|}
$\begin{array}{c}\text { Cooper } \\
(\mathrm{Cu})\end{array}$ \\
$127.00 \pm 5.68$ \\
$142.00 \pm 6.39$ \\
$133.00 \pm 5.83$ \\
\end{tabular}} & \multirow{3}{*}{$\begin{array}{c}\begin{array}{c}\text { Iron } \\
(\mathrm{Fe})\end{array} \\
320.00 \pm 7.19 \\
348.00 \pm 9.11 \\
320.00 \pm 6.78 \\
\end{array}$} & \multirow{3}{*}{\begin{tabular}{|c|}
$\begin{array}{c}\text { Mercury } \\
(\mathrm{Hg})\end{array}$ \\
$\mathrm{ND}$ \\
$\mathrm{ND}$ \\
$\mathrm{ND}$
\end{tabular}} & \multirow{3}{*}{$\begin{array}{c}\begin{array}{c}\text { Lead } \\
(\mathrm{Pb})\end{array} \\
0.09 \pm 0.00 \\
0.08 \pm 0.00 \\
\text { ND }\end{array}$} \\
\hline & AG2 & & & & & & \\
\hline & AG3 & & & & & & \\
\hline \multirow[t]{3}{*}{ Origanum majorana } & OM1 & ND & ND & $163.00 \pm 6.86$ & $657.00 \pm 5.45$ & ND & $0.14 \pm 0.00$ \\
\hline & OM2 & $0.01 \pm 0.00$ & $0.05 \pm 0.00$ & $131.00 \pm 4.70$ & $719.00 \pm 6.61$ & ND & $0.13 \pm 0.00$ \\
\hline & OM3 & $0.07 \pm 0.00$ & $0.05 \pm 0.00$ & $348.00 \pm 7.48$ & $473.00 \pm 3.74$ & ND & $0.95 \pm 0.01$ \\
\hline \multirow[t]{3}{*}{ Origanum vulgare } & OV1 & $0.03 \pm 0.00$ & $0.06 \pm 0.00$ & $201.00 \pm 5.78$ & $1375.00 \pm 32.64$ & $0.374 \pm 0.01$ & ND \\
\hline & OV2 & $0.21 \pm 0.00$ & $0.06 \pm 0.00$ & $198.00 \pm 5.77$ & $1460.00 \pm 59.40$ & $0.019 \pm 0.00$ & $0.04 \pm 0.00$ \\
\hline & OV3 & $0.33 \pm 0.00$ & $0.07 \pm 0.00$ & $222.00 \pm 7.71$ & $2471.00 \pm 77.56$ & $0.075 \pm 0$ & ND \\
\hline \multirow[t]{3}{*}{ Mentha piperita } & MP1 & $0.18 \pm 0.01$ & $0.01 \pm 0.00$ & $309.00 \pm 7.88$ & $6683.00 \pm 40.39$ & ND & $0.58 \pm 0.06$ \\
\hline & MP2 & $0.09 \pm 0.00$ & $0.05 \pm 0.00$ & $237.00 \pm 4.86$ & $2378.00 \pm 12.41$ & ND & $0.18 \pm 0.01$ \\
\hline & MP3 & ND & $0.10 \pm 0.01$ & $157.00 \pm 3.34$ & $673.00 \pm 6.35$ & $0.010 \pm 0.00$ & $1.28 \pm 0.08$ \\
\hline \multirow[t]{3}{*}{ Petroselinum crispum } & $\mathrm{PC} 1$ & $0.78 \pm 0.01$ & ND & $133.00 \pm 5.61$ & $1360.00 \pm 11.20$ & $0.083 \pm 0.00$ & $0.06 \pm 0.00$ \\
\hline & PC2 & $0.19 \pm 0.00$ & $0.05 \pm 0.00$ & $122.00 \pm 3.44$ & $336.00 \pm 2.38$ & $0.052 \pm 0.00$ & ND \\
\hline & PC3 & ND & $0.07 \pm 0.00$ & $123.00 \pm 4.03$ & $748.00 \pm 5.93$ & $0.026 \pm 0.00$ & $0.11 \pm 0.00$ \\
\hline \multirow[t]{3}{*}{ Thymus vulgaris } & TV1 & $0.03 \pm 0.00$ & $0.03 \pm 0.00$ & $191.00 \pm 6.35$ & $1314.00 \pm 12.39$ & $0.131 \pm 0.01$ & $0.07 \pm 0.00$ \\
\hline & TV2 & $0.42 \pm 0.01$ & $0.07 \pm 0.00$ & $131.00 \pm 4.73$ & $1449.00 \pm 11.32$ & $0.036 \pm 0.00$ & $0.09 \pm 0.00$ \\
\hline & TV3 & ND & $0.09 \pm 0.00$ & $169.00 \pm 5.32$ & $2578.00 \pm 13.62$ & $0.024 \pm 0.00$ & $0.11 \pm 0.00$ \\
\hline
\end{tabular}


Cooper $(\mathrm{Cu})$ is an essential trace element in humans and plants. It is a cofactor of many redox enzymes and plays a significant role in iron metabolism and many physiological processes including antioxidant defence, neuropeptide synthesis and immune function [3]. Also, $\mathrm{Cu}$ is essentially involved in normal growth and development of plants [31]. Elevated levels of $\mathrm{Cu}$ can cause gastrointestinal symptoms, hepatotoxicity, skin irritation and sensitization, and dysfunction of upper respiratory tract [4]. Sources of $\mathrm{Cu}$ contamination in plants could be linked to industrial and mining activities.

The $\mathrm{Cu}$ concentrations ranged from 4 to $24 \mathrm{mg} / \mathrm{kg}$ in samples of medicinal plants (Table III) and from 122 to $348 \mathrm{mg} / \mathrm{kg}$ in spices samples (Table IV). The highest levels were recorded in wild-growing samples of Calendula officinalis (CO4) (Table III) and Origanum majorana (OM 3) (Table IV). For similar species, the results obtained in this study are higher than other samples from Romania [8] or other regions [9, 10]. Also, all investigated samples of spices have a high $\mathrm{Cu}$ content (over $120 \mathrm{mg} / \mathrm{kg}$ ).

Iron $(\mathrm{Fe})$ is a biologically essential trace element for all living organisms. It is involved in a broad variety of cellular processes, namely electron transport and oxygen supply, cellular respiration, synthesis of DNA and proteins, cell proliferation and differentiation, regulation of gene expression and immunity [4]. Overdoses (above $20 \mathrm{mg} / \mathrm{kg}$ ) of iron are associated with gastrointestinal disorders, metabolic acidosis, cardiomyopathy, and renal and hepatic failure [4]. The results from this current study revealed a large variation of $\mathrm{Fe}$ content in selected plant samples. It was found in a range between 180 and $21020 \mathrm{mg} / \mathrm{kg}$ in samples of medicinal plants (Table III) and between 320 and $6683 \mathrm{mg} / \mathrm{kg}$ in spices samples (Table IV). The highest Fe level was obtained for a packaged sample of Calendula officinalis (CO3). In fact, all samples of Calendula officinalis contained large amounts of Fe (over $11000 \mathrm{mg} / \mathrm{kg}$ ) (Table III). Among investigated species, Anethum graveolens, Origanum majorana and Petroselinum crispum are characterized by a low accumulation of Fe. The Mentha piperita and Hypericum perforatum presented large variations between samples (even 10 times) (Tables III and IV). In the case of all samples, our results are higher than the reported $\mathrm{Fe}$ values for similar species from Mediterranean area [10], United Arab Emirates [5], or even Romania [8]. Mercury $(\mathrm{Hg})$ is a highly toxic non-essential metal that is considered to be a dangerous xenobiotic in living cells. The consequences of $\mathrm{Hg}$ toxicity mainly as organic mercury compounds include central nervous system damage, alteration of motor function, neurobehavioural, neurodevelopmental, immunological effects and cardiovascular and kidney injuries. Exposure of plants to $\mathrm{Hg}$ derives from natural sources (volcanic eruptions, emissions from the ocean) and anthropogenic activities (burning of fossil fuels, production of cement, mining, smelting, production of ferrous and non-ferrous metals) [21]. Hg levels were within allowable limits in our samples (Tables II, III and IV) except for a wild-growing sample of Tilia cordata $(0.106 \mathrm{mg} / \mathrm{kg})(\mathrm{TC} 4)$ and some packaged samples of Origanum vulgare (OV1) and Thymus vulgare (TV1) spices (0.374 and $0.131 \mathrm{mg} / \mathrm{kg}$, respectively). $\mathrm{Hg}$ was not detected in any of the samples of Hypericum perforatum, Anethum graveolens and Origanum majorana. Also, some packaged and wild-growing samples of Matricaria chamomilla (MC4), Ocimum basilicum (OB4) (Table III) and packaged samples of Mentha piperita (MP1, MP2) do not contained Hg (Table IV). It seems that the accumulation of $\mathrm{Hg}$ in plants depends primarily on the plants species, the degree of soil and atmosphere contamination, the season for harvesting [14]. Şenilă et al. reported high concentrations of $\mathrm{Hg}$ in perennial plants growing in the urban area of Baia Mare, a historical mining and metal processing centre from North-western Romania. The average content exceeded the permissible limit of $\mathrm{Hg}$ in plants $(0.22$ $\mathrm{mg} / \mathrm{kg}$ compared to $0.1 \mathrm{mg} / \mathrm{kg}$ ) [27]. Also, Ordak et al. showed a high accumulation of $\mathrm{Hg}$ in the leaves of the more commonly used perennial plants collected from the vicinity of busy streets in Poland [14].

Lead $(\mathrm{Pb})$ is a highly noxious metal for humans and the environment. It can affect any organ but causes toxic effects mainly on the nervous central system, the cardiovascular, haematological and renal systems. Plants' exposure to $\mathrm{Pb}$ results from: mining, smelting, steel industry, electroplating, inorganic fertilizers and pesticides use, fuel combustion, exhaust of automobiles and sewage sludge [22]. The content of $\mathrm{Pb}$ ranged from 0.04 to $2.03 \mathrm{mg} / \mathrm{kg}$ in samples of medicinal plants used as herbal teas (Table III) and from 0.04 to 1.28 $\mathrm{mg} / \mathrm{kg}$ in samples of spices (Table IV). The highest levels were found in wild-growing samples of Ocimum basilicum (2.03 mg/kg) (OB4) and Mentha piperita $(1.28 \mathrm{mg} / \mathrm{kg}$ ) (MP3). The concentrations of $\mathrm{Pb}$ were lower compared to the permissible limits defined by the European Pharmacopoeia and WHO/FAO (Table II), but they exceeded the maximum value required by the EU $(0.3 \mathrm{mg} / \mathrm{kg})$ for $75 \%$ of Ocimum basilicum samples, $66.66 \%$ of Mentha piperita samples and $33 \%$ of Origanum majorana, Matricaria chamomilla, Achillea millefolium and Tilia cordata samples, respectively (Tables III and IV). In general, the samples of plants collected from spontaneous flora are highly contaminated with lead. However, all values were inline or lower compared to those reported in other studies for similar plants from different regions of the globe [1, 5, 25], or even Romania [18].

\section{Conclusions}

In our study, forty-two samples of medicinal plants and spices commonly used in Romania were screened for six heavy metals contents (arsenic, cadmium, cooper, 
iron, mercury and lead). The concentrations of arsenic, cadmium were below the permissible limits.

Undetectable levels of arsenic, cadmium, mercury and lead were noticed for Hypericum perforatum. The content of mercury crossed the limits for some samples of Origanum vulgare, Tilia cordata and Thymus vulgare. Also, the concentrations of lead exceeded the limit recommended by EU for some samples of Achillea millefolium, Matricaria chamomilla, Mentha piperita, Ocimum basilicum, Origanum majorana and Tilia cordata.

The high load of iron and cooper can be associated with the collection site, such as the metallurgical type industrialized area of Galați city, Romania, in the case of wild-growing plants, and additionally, the processing methods for packaged samples. The findings of the study highlight the need of constant monitoring of heavy metals residues or other pollutants in order to ensure the quality and safety of herbal products. Therefore, the present study provides baseline data useful for a comprehensive assessment of heavy metals in medicinal plants from different parts of our country.

\section{Conflict of interest}

The authors declare no conflict of interest.

\section{References}

1. Baye H, Hymete A, Lead and cadmium accumulation in medicinal plants collected from environmentally different sites. Bull Environ Contam Toxicol., 2010; 84(2): 197-201.

2. Begum HA, Hamayun M, Zaman K, Shinwari ZK, Hussain AA, Heavy metal analysis in frequently consumable medicinal plants of Khyber Paktunkhwa, Pakistan. Pak J Botany, 2017; 49(3): 1155-1160.

3. Bost M, Houdart S, Oberli M, Kalonju E, Huneau JF, Margaritis I, Dietary copper and human health: Current evidence and unresolved issues. J Trace Elem Med Biol., 2016; 35:107-115.

4. Carranza-Álvarez C, Alonso-Castro ÁJ, MaldonadoMiranda JJ, Quantitation of $\mathrm{Cd}, \mathrm{Pb}$ and $\mathrm{Fe}$ in three medicinal plants (Justicia spicigera, Arnica montana and Hamelia pantens) from environmentally diverse locations of Huasteca Potosina, Mexico. Acta Universitaria, 2016; 26(5), 24-30.

5. Dghaim R, Al Khatib S, Rasool H, Ali Khan M, Determination of heavy metals concentration in traditional herbs commonly consumed in the United Arab Emirates. J Environ Pub Health, 2015; 2015: Art. ID 973878: 1-6.

6. European Pharmacopoeia, $6^{\text {th }}$ ed. Council of Europe: Strasbourg, 2007.

7. Finnegan PM, Chen W, Arsenic toxicity: the effects on plant metabolism. Front Physiol., 2012; 3: 182: 1-18.

8. Haidu D, Parkanyi D, Moldovan RI, Savii C, Pinzaru I, Dehelean C, Kurunczil L, Elemental characterization of Romanian crop medicinal plants by neutron activation analysis. J Analyt Meth Chem., 2017; 2017: Art. ID 9748413: 1-12.
9. Idrees M, Rafiq S, Ullah S, Jan FA, Khan MN, Mabood F, Heavy metals level of medicinal plants collected from selected district in Khyber-Pakthtunkhwa, Pakistan. Farmacia, 2018; 66(5): 861-865.

10. Koc H, Sari H, Trace metal contents of some medicinal, aromatic plants and soil samples in the Mediterranean region, Turkey. J Appl Chem Res., 2009; 8: 52-57.

11. Kulhari A, Sheorayan A, Bajar S, Sarkar S, Chaudhury A, Kalia RK, Investigation of heavy metals in frequently utilized medicinal plants collected from environmentally diverse locations of north western India. SpringerPlus, 2013; 2: 676: 1-9.

12. Lisa LE, Carac G, Barbu V, Robu S, The synergistic antioxidant effect and antimicrobial efficacity of propolis, myrrh and chlorhexidine as beneficial toothpaste components. Revista de Chimie, 2017; 68(9): 2060-2065.

13. Official Journal of the European Union: Commission Regulation (EC) No. 420/2011 of April 29, 2011, amending Regulation (EC) No 1881/2006 setting maximum levels for certain contaminants in foodstuffs, 2011.

14. Ordak M, Wesolowski M, Radecka I, Muszynska E, Bujalska-Zazdrozny M, Seasonal variations of mercury levels in selected medicinal plants originating from Poland. Biol Trace Elem Res., 2016; 173(2): 514-524.

15. Oprea E, Tuchiluş C, Aprotosoaie AC, Cioancă O, Trifan A, Grădinariu V, Miron A, Hăncianu M, Assessment of the microbial load of some medicinal plants commonly used in Romania. Rev Med Chir Soc Med Nat Iasi, 2015; 119(1): 267-272.

16. Oprea E, Pintilie V, Bufnea V, Aprotosoaie AC, Cioancă O, Trifan A, Hăncianu M, Radionuclides content in some medicinal plants commonly used in Romania. Farmacia, 2014; 62(4): 658-663.

17. Oprea G, Michnea A, Mihai C, Senila M, Roman C, Jelea S, Butean C, Barz C, Arsenic and antimony content in soil and plants from Baia Mare Area, Romania. Am J Environ Sci., 2010; 6(1): 33-40.

18. Radulescu C, Stihi C, Popescu IV, Ionita I, Dulama ID, Chilian A, Bancuta OR, Chelarescu ED, Let D, Assessment of heavy metals level in some perennial medicinal plants by flame atomic absorption spectrometry. Rom Rep Physics, 2013; 65(1): 246-260.

19. Ratnaike RN, Acute and chronic arsenic toxicity. Postgrad Med J., 2003; 79(933): 391-396.

20. Satarug S, Garrett SH, Sens MA, Sens DA, Cadmium, environmental exposure, and health outcomes. Environ Health Perspect., 2010; 118(2): 182-190.

21. Science for Environment Policy. Tackling mercury pollution in the EU and worldwide. In-depth Report 15 produced for the European Commission, DG Environment by the Science Communication Unit, UWE, Bristol, 2017, http://ec.europa.eu/scienceenvironment-policy.

22. Şlencu BG, Ciobanu C, Cuciureanu R, Anton A, Ciobanu S, Solcan G, Solcan C, Protective effects of selenium on hepatotoxicity caused by subacute experimental combined exposure to cadmium and lead in rats. Farmacia, 2018; 66(5): 866-878.

23. SR EN 14084. Foodstuffs. Determination of trace elements. Determination of lead, cadmium, zinc, copper and iron by atomic absorption spectrometry (AAS) after microwave digestion, 2003. 
24. SR EN 13806. Foodstuffs - Determination of trace elements - Determination of mercury by cold-vapour atomic absorption spectrometry (CVAAS) after pressure digestion, 2003.

25. Stanojkovic-Sebic A, Pivic R, Josic D, Dinic Z, Stanojkovic A, Heavy metals content in selected medicinal plants commonly used as components for herbal formulations. J Agric Sci., 2015; 21(2015): 317-325.

26. Stănescu U, Hăncianu M, Cioancă $\mathrm{O}$, Aprotosoaie $\mathrm{AC}$, Miron A, Medicinal plants from A to Z, $3^{\text {rd }}$ edition, Polirom Publishing House, Iaşi, 2018, (available in Romanian)

27. Şenilă M, Levei E, Şenilă LR, Oprea GM, Roman CM, Mercury in soil and perennial plants in a miningaffected urban area from Northwestern Romania. $J$
Environ Sci Health, Part A: Toxic/Hazardous Subst Environ Engin., 2012; 47(4): 614-621.

28. Tudorache A, Marin C, Badea IA, Vladescu L, Determination of arsenic content of some Romanian natural mineral groundwaters. Environ Monit Assess., 2011; 173(1-4): 79-89.

29. World Health Organization, Traditional Medicine Strategy (2002-2005), World Health Organization, Geneva, Switzerland, 2002.

30. *** WHO. Guidelines for Assessing Quality of Herbal Medicines with Reference to Contaminants and Residues, 2007, http://apps.who.int/medicinedocs/ documents/s14878e.pdf.

31. Yruela I, Copper in plants. Braz J Plant Physiol., 2005; 17(1): 145-156. 